ÁGNES DOMONKOSI ${ }^{1,3}$ - TÍMEA H. TOMESZ²

\title{
ON THE LINGUISTIC CONSTRUAL OF SOCIAL RELATIONS AT AN ONLINE GENERAL ASSEMBLY OF THE HUNGARIAN FOOTBALL FEDERATION ${ }^{1}$
}

\author{
${ }^{1}$ Institute of Special Education, Eszterházy Károly Catholic University \\ ${ }^{2}$ Department of Hungarian Linguistics, Eszterházy Károly Catholic University \\ ${ }^{3}$ Hungarian Research Centre for Linguistics, Institute of Language Technology and \\ Applied Linguistics
}

\section{Introduction}

The measures imposed from March 2020 to curb the coronavirus epidemic, including restrictions on larger events, social gatherings swiftly transformed all domains of public life. Several tasks of education, business and public life were forced into the online space, with the consequence that certain communicative routines, practices were also adapted to the new situation. The goal of this case study is to analyse what linguistic devices contributed to the construal of social relations at an online general assembly of the Hungarian Football Federation (HFF), and how their use reflected the speech situation characterized by a variety of communicative circumstances. Based on a study of the complete recorded material of the general assembly, the analysis explores how this formal and public event was linguistically organized in the online space, and how the novel communicative situation affected the construal of linguistic as well as nonlinguistic rituals. The analysis draws on the ritual model of communication. With regard to the construal of social relations, it focuses on linguistic operations, taking into account variants and combinations of address forms, personal references and greetings, i.e. elements contributing to attitudinal deixis.

The goal of the analysis is to identify communicative fetaures of this official, formal and public event that derive from the online setting, and highlight the ways in which public events are necessarily transformed as a function of online and hybrid communication (independently of the epidemic situation). In addition, the paper also seeks to demonstrate what elements of the rituals of official and public events (cf. Domonkosi - H. Tomesz 2020a, 2020b) can be transferred to the online space, and how. By investigating the operations of attitudinal deixis, the paper sheds light on interactional pressures derived from the epidemic situation,

1 The research was supported by grant nr. K 129040 of the National Research, Development and Innovation Office (NKFIH) and by Visegrad Scholarship Program, Project n.: \#52111723 (Á. D.). 
ad hoc devices presumed by certain participants to be adequate in the situation at hand, experimental communicative procedures as well as communicative and linguistic signals of a lack of sufficient online experience.

The paper begins by briefly presenting the concepts and theoretical background of the study (2), then moves on to introduce the empirical material and the methods of analysis (3). The discussion of results is then organized into the following thematic groups: the inexperience of participants in the communicative situation of online video conferences (4.1), the construal of personality in the online public space (4.2), rituals of official acts of the general assembly (4.3), acts of technical import demanded by the online setting (4.4) and greetings and good wishes referring to the epidemic situation (4.5). Finally, the summary (5) gives an overview of the major features of linguistic operations serving the management of social relations at an online public event which crucially affect the functioning of attitudinal deixis.

\section{Theoretical background}

In our analysis of the general assembly's recording, we build on the results of research on special features of online communication, interpreting the assembly itself as a specific type of speech event. Our approach draws heavily on the ritual model of communication and language use. In terms of linguistic phenomena, while all aspects of construal are taken into account, we primarily focus on the operations of attitudinal deixis.

\subsection{Online interactions and online publicity - the complex social and communicative situation of the public video conference}

With online forms of interaction becoming ubiquitous, new communicative spheres and styles of communication are constantly emerging, which has a major impact on the assessment of traditional linguistic and communicative practices as well. In online situations, new types of speech event (cf. Hymes 1974) are created by the fact that relations between speaker, addressee, audience, channel, theme and arrangement considerably depart from the norms of face-to-face communication.

Certain types of unline utterances create a complex situation, with the blurring of boundaries between intimate, personal, social and public spheres of communication (cf. Bös-Kleinke 2017), the mixing of public and private patterns of behaviour (cf. Sebestyén-Gayer 2016: 145-146) also producing new, mixed qualities in linguistic behaviour. In terms of language activity, as a function of the broad availability and public, online distribution of messages, even communication that is intended to be personal may be endowed with a public, social role. Additionally, discourse participants in the online space are less aware of the pressure that public speech may exert on linguistic elaboration, thus utterances with public import may also drift toward rather personal style (cf. Domonkosi 2018a). 
Despite technological advancements, computer-mediated communication was long dominated by written forms of exchange (cf. Pólya 2011); however, the lockdown situation brought about a rapid expansion of online spoken interactions. What is more, multi-participant video conversations came to be quickly adopted in a range of social relations. Family conversations, birthday parties, business meetings, lessons and scientific conferences were all moved to the same virtual space, and the participants' lack of experience in handling the supporting technology also reinforced similarities in communication in these otherwise highly diverse situations.

In their traditional form, general assemblies represent a subtype of public meetings; they are meticulously planned and prepared, ritually organized communicative processes unfolding in consecutive stages. They are sequences of formalized actions in which participants with designated roles act in compliance with specific rules. Since assemblies make for a direct form of communication, they are characterized by spatial and temporal proximity. However, in the networkbased communicative situation of video conferences, features of direct, indirect and mediated communication are blurred, with major changes affecting the spatial and temporal conditions that define particular spheres of communication. In other words, a hybrid, convergent communicative situation has emerged in which previously distinct levels, forms and roles of communication are combined (Andok 2016, Szüts 2018).

Online meetings are similar to traditional ones in that they are also preplanned and organized by rules in a ritual manner (Borgulya 2007: 172-179); however, they are also different in terms of the manner of interactivity, the complexity of potential directions of information spread, and the hybridity of communicative situations. By being broadcast on the internet, they also become public, capable of being accessed and commented on by several people at the same time. Some participants have clear identities, while others remain undefined. The blurring of spatial, temporal and social boundaries has the effect of making it more difficult for participants to identify and manage social context (Andok 2016: 107).

In this complex communicative situation, personal messages are also integrated into on-stage, i.e. openly accessible actions (cf. Goffmann 1956). The roles of discourse participants, their relations to each other are also re-defined. The strictly formal, protocol-based overall framework of general assemblies is cross-cut by informal behavioural practices that govern everyday relations (mostly based on direct acquaintance) between participants knowing each other to varying degrees (cf. Balázs 2010).

\subsection{Communication as ritual}

Rituals are specific forms of social behaviour, recurring and simplified episodes of communication (Alexander 2004) which are primarily distinguished from other communal actions by their additional symbolic meaning. All communicative acts can be regarded as rituals whose form receives more emphasis and whose 
execution is crucial for the felicitousness and success of interaction. In many cases, communication serves a predominantly ritual function, and it almost always contains ritual elements. The theory that considers communication as ritual is concerned with such issues as the structure and regulation of discourse, roles, norms, orientations, values, meanings, and all of these are viewed from the perspective of symbol use. Researchers working in the theory investigate how symbolic forms function, how they contribute to the creation of meanings, values (Andok 2017: 19). An important function of rituals is that they allow time to be better apprehended, managed and interpreted. By virtue of being repeated at certain intervals, they facilitate the functioning of a community, reinforcing and representing its identity and creating shared memory. As schematic, conventional verbal and non-verbal actions, rituals emerge from interactions. They reinforce relationships, affecting interpersonal relations in complex ways (Kádár 2013: 11-12, Kádár-Petykó 2016: 3).

One key feature of rituals is their repetition, the recurrent nature of actions (cf. Andok 2017: 103, Kádár 2013: 15, Neulinger 2013: 104). They have special meaning for both the individual and the community, and also serve to express and reinforce identity. Within ritual communication, two main categories can be distinguished (Andok 2017:16): i. formal rites, ceremonies which are held at particular places and times and attract special attention (such as various competitions and campaigns) and formalized everyday activities (such as greetings, handshakes) during which it has meaning and significance how they are enacted. Thus, a conversation by a cup of coffee and a family birthday celebration can be considered rituals just as much as workplace meetings or national holidays. Behavioural patterns associated with such rituals can be observed at both individual and community levels but they primarily receive attention (metapragmatic reflection) at times of norm violations (Kádár 2013: 151).

\subsection{The notion of attitudinal deixis and its role in construing interpersonal relations}

The main linguistic phenomenon which has been subjected to analysis is the operation of attitudinal deixis. Attitudinal deixis is defined by cognitive pragmatics as a linguistic operation that involves the participants' social world in the intepretation of discourse, activating contextual information that derives from the processing of interpersonal relations in the speech event (cf. Tátrai 2011: 127). In other words, those linguistic operations can be subsumed under the concept of attitudinal deixis which refer to the participants' social identities, their relation to each other or to another person or phenomenon (Verschueren 1999: 20-21).

In Hungarian, the most characteristic operations of attitudinal deixis include variants of $T$ and $V$ address, nominal address forms, titles, ranks, honorifics and greetings. In addition, the nature of social relations may also play a role in the speaker's self-representation and the way in which characters of the referential scene are referred to (Tátrai 2011: 135). Variants of pronouns and 
nouns designating discourse participants and characters of the referential scene, their degrees of specificity, their roles in referring to functions, positions or ranks, and their manner of combination are also shaped by features of the social relation between participants.

In public situations (e.g. meetings, negotiations), attitudinal deixis has a complex function. Its role is not only to designate and negotiate relationships but also to represent relations and thereby create a formal ritual framework for communication (cf. Domonkosi 2018a). Under the adopted interpretation, operations of attitudinal deixis do not simply reflect or portray the variability of social relations and communicative situations but rather also make an active, dynamic contribution to their negotiation.

\section{Research material and method}

The material selected for analysis was the 2020 general assembly of the Hungarian Football Federation, conducted online via the Zoom.us application, which was broadcast live and made available for later viewing as well. The unfolding situation was more complex than that of usual video conferences, online meetings that became common in the lockdown period and provided a venue for enacting social relations. The reason for this added complexity was that a multi-participant, offical and highly regulated event (held every year with media participation and recorded on video) had been transferred to the online space. The practices of video conferences in everyday, educational, business and scientific contexts during the early phase of the lockdown period invite analysis along various communicative criteria; however, the use of such material may be mired with difficulty on the grounds of personal rights, legal considerations and business interests alike. By contrast, owing to the event's public interest and open accessibility, the online general assembly of the HFF supplied complete material that lent itself naturally to research. Moreover, the roles of speakers (relevant for the meeting at hand) were clearly identifiable, which supported the intepretation of linguistic strategies for construing their social relations. Additionally, since HFF general assemblies are held every year, it was possible to compare the 2020 event with previous, face-to-face meetings.

The event supplying the study's empirical material was highly complex in terms of its communicative situation, as it simultaneously featured interpersonal and public or societal communicative situation types, with a combination of direct and indirect forms of communication (Buda 1994: 151).

The agenda of the online general assembly on 21 April 2020 was identical to those of traditional face-to-face assemblies. With a few exceptions it followed the previously established sequence of agenda items, and offered an opportunity for open comments as afforded by the technical background (W1). As assemblies have a major role in defining sports life, they are always meticulously planned, and this is particularly true for the 2020 assembly introducing new, not yet 
routinely adopted technical apparatus. The assembly witnessed important decisions and actions with strong legal consequences. The members elected their president as well as board members, and voted on accepting the previous year's financial report. Participants had received the documentation beforehand, so they had an opportunity to prepare for decisions (W2, W3, W4).

The recorded video material of official acts performed at assemblies are posted by HFF every year on its own Youtube channel. From the 2020 assembly, a total of 1 hour and 28 minutes of official material was made public (W5). In our analysis, however, we used not only this version but also the unofficial material, which is also available on the internet and is longer by 7 minutes (W6), in the interest of observing challenges posed by communicative, technical difficulties during the lockdown period.

In order to facilitate comparison between online and face-to-face assemblies, we also examined the linguistic material of the 2019 general assembly (W7). In the present paper, no detailed analysis is given of this previous assembly but some of its linguistic features are presented as a standard of comparison.

At the thoroughly analysed 2020 assembly, 70 delegates were present along with HFF office-holders and administrative personnel. Key participants included HFF president Sándor Csányi, who was also in charge of opening the official part of the programme, and secretery general Márton Vági, who also acted as chair during the meeting.

In our analysis, all dimensions of communicative features were taken into account. Our selection of linguistic variables was informed by the assumption that modelling the types and functions of attitudinal deictic operations would allow us to identify key features of this online communicative event.

The entire linguistic material of the online assembly was systematically processed. In the course of analysis, we coded linguistic elements that referred to i. the social identity of discourse participants, ii. relations between participants or iii. the participants' relations to other referents. Subsequently, we defined the role of these elements in the construal of the social situation. From among the devices of attitudinal deixis, the following linguistic variables were adopted: T vs. $V$ address, various nominal and pronominal forms of address, personal references, greeting formulas and salutations, and varied instantiations of speech acts contributing to the construal of interpersonal relations, including requests. Moreover, for the purposes of interpretation, we also relied on stylistic aspects of attitude marking (cf. Tátrai-Ballagó 2020).

Operations of attitudinal deixis are highly complex at a public online event that is broadcast live and made available for later viewing, as their functioning informs and is informed by complex role expectations and communicative features of the activity being performed. Our analysis was based on the assumption that various operations of attitudinal deixis all contributed to the management of personal relations and the maintenance of linguistic practices associated with official acts of protocol, thus their examination would bring benefits for understanding the dynamics of communicative relations. 
Our transcription of the general assembly's dialogues was carried out in consideration of the various transcription procedures of conversation analysis (cf. Boronkai 2009) but with necessary simplifications as dictated by the goals of analysis. Dialogue participants were registered with their full names, and our punctuation protocol followed the rules of Hungarian orthography. The (.) mark indicates a pause, the - symbol stands for short hesitation, ö, ööö are used to designate filled pauses of variable length, curly brackets \{\} indicate simultaneous speech, and the [...] mark signals omitted passages. In the English translations of the recorded dialogues, short filled pauses are signalled by uh and longer filled pauses by um.

\section{Results: online inexperience and the extension of publicity}

The context-sensitive interpretation of linguistic operations at the video conference under study reveals some typical patterns in the organization of social relations. Aspects of the linguistic construal of social relations are presented here in five subsections. Firstly, we discuss linguistic devices for communication management whose use is motivated by the participants' inexperience in online video conferences (4.1). Secondly, the features and functions of personal messages elevated into the public online space of the conference are analysed (4.2). Thirdly, we examine elements contributing to the ritual of the general assembly as an official event (4.3). Fourthly, we turn to devices serving the technical organization of the conference (4.4). Finally, we analyse references to the epidemic situation as they appear in the rituals of greetings and good wishes.

\subsection{Evidence of inexperience in online conferences}

In the lockdown period, multi-participant online video conferences became significantly more common and extended to several new domains of application. The online general assembly under study had been preceded by careful preparatory work, also in the interest of ensuring the legal validity of its official acts. Still, the event saw a number of incidents that resulted from the participants' technical inexperience or lack of awareness of the complex communicative situation. Utterances indicating insufficient online experience can be primarily observed at the beginning of the broadcast material. These parts had been removed from the official recording that was made public by the HFF. They did not belong to the material that was meant to be officially recorded, i.e. to the publicized ritual of the general assembly.

In the first moments of the full recorded material, more than 70 participants are already present in the online space; however, only 12 of them become visible or audible in some way in the minutes leading up to the official opening. At this stage, it is not only linguistic elements that indicate lack of experience in this kind of situation but also the randomness with which participants join the conference visually. For example, several participants appear on the screen from time to 
time (presumably because their microphones are on) even when they do not actually intend to join the dialogue.

Presumably it is also users lacking experience in the technical background and in the conventions of video conferences who tend to go onstage in the first, unofficial part of the general assembly. At this phase in the recording, some utterances are directed merely at the checking and regulation of visibility and audibility, on the maintenance of the communication channel. Right at the start of the unofficial recording, a dialogue of this kind occurs, where a participant identifies himself and requests feedback.

(1)

Nagy Sándor: Halló, jó napot, Nagy Sándor vagyok Csákvárról, hallanak?

[képpel nem azonosítható beszélő] Hallunk, Sándor, \{rendben.

Popovics György: Igen\}

Nagy Sándor: Oké, Köszönöm. (.) Kell valamit tennem? Vagy minden rendben van?

Popovics György: Halkítsd le a mikrofont a bal \{alsó sarokban.

Hehl Zoltán: Igen, igen, igen\}

Nagy Sándor: Igen, csináljuk.

Sándor Nagy: Hello, good afternoon, I'm Sándor Nagy from Csákvár, can you hear( $(\mathrm{V}) \mathrm{me}$ ?

[unidentifiable speaker] We can hear you Sándor, \{it's OK.

György Popovics: Yes\}

Sándor Nagy: OK, thank you. (.) Do I need to do something? Or is everything OK?

György Popovics: Mute your microphone on the left \{in the bottom corner.

Hehl Zoltán: Yes, yes, yes\}

Sándor Nagy: Yes, we are doing it.

The $V$ form used by the first speaker in his opening utterance in which he identifies himself is peculiar because participants of the general assembly are characteristically using $T$ forms throughout the meeting, they only resort to the mutual use of $\vee$ with dr. János Tamás Gelei, who is in charge of providing technical support, i.e. who is not strictly speaking a member of the community. Therefore, in the case at hand, the $V$ verb form in opening utterance of (1) also indicates the speaker's uncertainty. By contrast, the answers he receives are personal, addressing the speech partner by his given name and employing $T$ forms.

The longer, uncut recording begins with the dialogue in (1), it has no preplanned format designed for the public. The starting moment of the recording appears be random, and there is no information about how other participants joined the meeting. The official recording made public by HFF begins with the 
assembly's official opening, which indicates what the federation considers important enough to be shared with the public. However, one feature of online communication is that whatever has been made public remains in some way accessible and analysable (Dessewffy-Láng 2015: 160). And indeed, this preparatory phase of the assembly can be fruitfully used for analysing the ways in which the participants' inexperience in organizing official, public online events is manifested.

The challenges posed by the need to join a new type of communicative situation receives attention in an overt way, as illustrated by the following utterance that gets widely shared against the speaker's communicative intention. Here the speaker is presumably commenting on his own actions and referring to other participants while talking to an external speech partner.

(2) Gács Pál: Itt vannak megint az urak, leveszem a hangot.

Pál Gács: The gentlemen are here again, I'm muting the audio.

Technical challenges and inexperience are also suggested by the fact that several participants have assistants beside them. For example, when János Süli, a minister without portfolio, joins the assembly, another participant is also with him, providing technical assistance in hardware setup. In the case of Károly Szita, first his IT assistant joins in, to which the chair of the assembly reacts in a humorous manner.

Besides participants going onstage because of their inexperience, the preparatory phase also features utterances by those holding key positions in HFF's leadership or fulfilling important social functions. President Sándor Csányi's opening speech is part of the pre-planned schedule. His utterance transforms the communication space, making the event more official. His greeting is met with individual greeting responses by many before the president is again emphatically greeting everyone and refers to attendance check, in a way preventing a situation in which all members of a community of around 80 participants might want to join the ritual of greetings. The president's strategic behaviour comes in response to the lack of conventional rules of online behaviour. And when he mentions the vice president by his given name, this does not only create a sense of solidarity among participants but also indicates that the official procedure has not yet begun.

(3)

Csányi Sándor: Jó napot kívánok mindenkinek!

Zelei János Tamás: Jó napot kívánok, elnök úr!

Süli János: Jó napot kívánok!

Dr. Róka Géza: Jó napot!

Csányi Sándor: Jó napot kívánok! Mindenkit üdvözlök! (.) Majd ö Marcira hárul, hogy a létszámot ellenőrizze, mert én most csak a képernyőkön tudok (.)\{számolni.

[képpel nem azonosítható beszélő] Igen\} 
Sándor Csányi: Good afternoon to everyone.

János Tamás Zelei: Good afternoon, Mr President.

János Süli: Good afternoon.

Dr. Géza Róka: Good afternoon.

Sándor Csányi: Good afternoon. I'm greeting everyone. (.) Then uh it'll be up to Marci to check the attendance because I can only count on the (.) \{screens.

[speaker not identifiable by image] Yes\}

The preparatory, informal part of the general assembly may remind one of the initial phase of face-to-face assemblies, during which (before the official part of the programme begins) various noises can heard, including address forms and greetings. However, at face-to-face assemblies, several communicative acts are running in parallel among participants, none of which receives special prominence. Moreover, the preparatory phase of such assemblies is neatly separated from the official event itself. By contrast, in the online broadcast, communicative acts during the preparatory phase are foregrounded by appearing on the screen, and since they are performed under the same technical conditions, their separation from the assembly's official parts is less conspicuous.

Even the official part of the programme includes incidents when norms of behaviour during the online conference become pronounced, partly indicating the lack of conventionalization of the relevant rituals. After the official voting has begun, and rituals for implementing the online assembly are being negotiated (see 4.4), Sándor Csányi uses a given name address to attract attention and interrupt the official act, remarking that even though he does not have a right to vote, he did vote. The asymmetry of address forms in the dialogue does not simply reflect the two parties' relationship. The president's use of given name address is aimed at highlighting a departure from the event's regular structure, whereas the vocative form in the reply, which foregrounds the president's rank, is associated with the official procedures of the assembly.

(4)

Csányi Sándor: Marci, én is szavaztam most, úgyhogy akkor húzzatok le!

Vági Márton: Köszönöm, elnök úr, hogy jelezted, ezt a gép regisztrálja, és a végleges jegyzőkönyv, amit majd az ügyészség számára beadunk, majd csak azokat a szavazatokat tartalmazza, amelyek jogosultak a szavazásra.

Sándor Csányi: Marty, I've also voted now, so please take me off! Márton Vági: Thank you, Mr President, for signalling this, this is registered by the computer and the final minutes which will be handed in are going to contain the votes of only those who were eligible to vote. 
During the president's report about the previous year, a participant's inadequate behaviour receives verbal comment. Since the president interrupts the most protocollary part of the programme to reprimand a delegate, he attracts attention by a vocative form combining the addressee's family name and a title as characteristic of the official practice of the community.

(5)

Csányi Sándor: [...] Garancsi úr! Ha egyszer leülnél, mert mozog az egész képernyő miattad, azt megköszönném! Jó? Tehát ilyen Mindenki ül, és te mozgóképet ööö - ööö - mutatsz magadról, úgyhogy ööö - próbáld meg fixálni a helyzetedet. Nem rossz a helyzeted, mert második vagy egyébként a bajnokságban. De nem ezért szóltam.

Sándor Csányi: [...] Mr Garancsi! If you could please sit down because the entire screen is moving because of you, I'd be thankful! OK? So it's like - Everybody is sitting and you're sharing um a moving picture of yourself so um - please try to fix your position. Your position is not bad by the way because you are second in the championship. But that's not why I was telling you this.

In this warning about inadequate behaviour caused by inexperience (5), the address form Garancsi úr'Mr Garancsi' complies with the usual linguistic practice of the official procedure. It deserves mention that before the official part of the assembly, Mr Garancsi was at one point addressed by his nickname (Pista) in the same dyad.

\subsection{Personal rituals in the public space}

The informal, unofficial preparatory phase of the assembly involves casual rituals of everyday communication, i.e. aspects of small talk and banter which belong to interactional rituals pertaining to the construal of personal relations. Before the official opening, these rituals have a complex role. On the one hand, they help observe the phatic maxim (Leech 1983: 142) by allowing the participants to avoid silence. On the other, they serve to make up for the absence of face-to-face encounters and associated rituals in the lockdown period; they create proximity at a time of social distancing.

Our previous analyses have already revealed that sports events are often characterized by the simultaneous presence of personal and official styles of communication, the duality of construing relationships (cf. Domonkosi-H. Tomesz 2020a, 2020b). This is also true for the 2019 face-to-face general assembly we have studied, especially in Sándor Csányi's utterances that address or refer to participants both in an informal way (by their given names) and in an official fashion. However, personal dialogues receive even more specificity and longer duration in the preparatory part of the online assembly. Relatively long informal 
dialogues and personal networking are presumably also a key aspect of faceto-face assemblies but they are more neatly separated from the official part of these events, thus they are not featured in recordings.

At the online general assembly under study, all instances of personal small talk involve Sándor Csányi (which is motivated by his role as president), and in most cases they are initiated by him. These dialogues raise the operations of personal conversations into the public space of online discourse. At several points, it can be perceived that the participants are consciously bringing personal relations on stage (cf. Goffmann 1956).

(6)

Csányi Sándor: Püspök úr, valami ígéretet nem tud tenni nekünk itt az év hátralévő részére? Nincs valami jobb információja? A mikrofont kapcsold be!

(.)

Csányi Sándor: A képernyőd bal oldalán (.) van egy mikrofonjel. Kiss-Rigó László: Kezdés május közepén!

(.)

Csányi Sándor: Bárcsak igazad lenne (.) majd a beszédben elmondom, amit akarok figyelmeztetést, a lebonyolítást illetően.

Sándor Csányi: Your excellency, can't you promise something for us here for the remaining part of the year? Don't you have some more information? Please switch on the microphone!

(.)

Sándor Csányi: On the left side of your screen (.) there is a microphone symbol.

László Kiss-Rigó: Starting in the middle of May!

(.)

Sándor Csányi: If only you were right (.) in the speech I will tell you what I want, a warning about the implementation.

The above conversation involves László Kiss-Rigó, the bishop of Szeged-Csanád and founder the Grosics Academy. The dialogue has a phatic function, it is meant to represent and portray the two parties' relationship for the audience. The oscillation between publicity and personalness is shown by the fact that the opening turn first features formal address and V-type questions (with thirdperson grammatical forms) before Csányi switches to T-type communication for giving the bishop a direct technical instruction about turning on the microphone.

In the unoffical, preparatory part of the general assembly, the president initiates several dialogues of this kind. In one case, small talk is initiated not by him but by István Garancsi, owner and president of the football club MOL Fehérvár FC from the town of Székesfehérvár. In this dialogue, the speech partners perform negotiation about the customs of the online general assembly, with regard to the 
dress code rather than verbal behaviour (for more details, see 4.4). From István Garancsi's excessively personal utterances evoking shared memories, it seems as if he was not completely aware of the boundary between personalness and publicity in the online space of the assembly. His downright confidential tone can be perceived not only from the topic of this dialogue but also from operations of address and personal reference, more specifically the use of nicknames.

(7)

Garancsi István: Szia, Sándor!

Csányi Sándor: Szia, Pista!

Garancsi István: De elegáns vagy!

Csányi Sándor: Hát nem vetted észre, hogy közgyúlés van, küldöttközgyúlés?

Garancsi István: De.

Csányi Sándor: Hát akkor remélem, te is úgy öltöztél, hol a nyakkendőd?

Garancsi István: Nekem itt póló van rajtam, a legkedvesebb pólóm. Csányi Sándor: Igen? Na, hát az is megtiszteltetés nekünk. Egyáltalán, hogy részt veszel.

Garancsi István: De majd mindjárt felveszem azt a pólót, amit ajándékba szereztem, ami egyszer nagyon megtetszett, még tavaly (.) itt van, a \{Karcsi megvette Londonban.

Csányi Sándor: És, csak nem adtad még ide\}

István Garancsi: Hello, Sándor!

Sándor Csányi: Hello, Pista [Steve]!

István Garancsi: Look how elegant you are!

Sándor Csányi: Haven't you noticed that this is an assembly, a general assembly?

István Garancsi: I have.

Sándor Csányi: Well then I hope you are also dressed accordingly, where is your tie?

István Garancsi: Me I have a T-shirt on, my favourite T-shirt.

Sándor Csányi: Do you? Well, that's an honour for us too. Even your participation is.

István Garancsi: But l'Il soon put on that T-shirt that I got as a present, the one I really took a liking to last year (.) here it is, \{Karcsi [Charlie] bought it in London.

Sándor Csányi: And, you haven't given it to me yet\}

The official part of the assembly is not characterized by personal utterances. However, in Sándor Csányi's report, his reference to a guest UEFA official by his given name has the function of signalling acquaintance and proximity. 
(8)

Csányi Sándor: [...] Sportdiplomácia terén, ahogy a Jozef is mondta az UEFA-tól, valóban több jelentős esemény is történt [...]

Sándor Csányi: [...] In the area of sports diplomacy, as Jozef also said from UEFA, several significant events indeed occurred [...]

\subsection{Elaborating the ritual of the general assembly as an official event}

Traditionally, a general assembly is a ceremonial event consisting of formal actions that are performed in a set order, according to rules, with a well-defined beginning and end. The opening ritual contains the greeting of participants, the introduction of key figures and the clarification of rules, whereas the closing part involves the registration of actions that have been performed and bidding farewell.

Reports, decisions and the regulated order of the event are registered in minutes, legitimizing the community's actions and the rules that define them. The events' participants act in accordance with designated roles (chair, minutes taker, president, committee leaders, delegates, media workers). The 'master of ceremonies' is the chair of the meaning, whose task is to coordinate the participants' actions, clarify rules, and oversee their observation. At the beginning of an assembly, participants ritually decide on who should serve as chair and which other participants should oversee the formal order of implementation as minutes taker and attestor. As the comparison of recordings has revealed, the sequence of actions during the 2020 online assembly was identical to what had characterized traditional assemblies in previous years. However, an online assembly requires more functions to be fulfilled, since it requires digital literacy and technical staff, with its implementation in need of technical preparation and monitoring.

The online assembly under study conforms to the rules and customs of traditional meetings in that the event is formally opened by HFF president Sándor Csányi. It follows from the online organization of the assembly that he receives the floor from the technical organizer (see 4.4 for details). His opening speech begins with a formal address enumerating all participants.

(9)

Dr. Zelei János Tamás: Elnök úr, elvégeztük a létszámellenőrzést, \{és mindent rendben találtunk, hetven küldöttünk van jelen pillanatban a hetvenöt küldöttből bent, és elkezdhetjük a küldöttközgyűlést! Csányi Sándor: Igen\}

(.)

Csányi Sándor: Köszönöm szépen, tisztelettel köszöntök mindenkit, a küldöttközgyűlés tagjait, küldötteket természetesen, a média képviselőit. Hölgyeim és uraim, kedves vendégeink, akkor elkezdjük rendhagyó közgyűlésünket, ami a 2019-es évet zárja le. [...] 
Dr. János Tamás Zelei: Mr President, we have performed attendance check and we have found everything to be in order, at present we have 70 out of 75 delegates in here, the assembly can be started.

Sándor Csányi: Yes\}

(.)

Sándor Csányi: Thank you very much, I am greeting everyone with respect, the members, delegates of the assembly naturally, and media representatives. Ladies and gentlemen, dear guests, we are starting our unorthodox general assembly that closes the year 2019. $[\ldots]$

The introductory part of the president's speech is longer than usual (with respect to previously valid norms). It serves to justify the online convention of the general assembly, marks the president's adaptation to the epidemic situation and spells out his evaluation of the communicative context.

A highly formal element of the general assembly is the greeting speech delivered by UEFA delegate Jozef Kliment. Its English text has been written beforehand, and it is accompanied by part-by-part Hungarian translation. The formal and official nature of the speech is strengthened by recurring $V$ pronominal forms (Önök szövetsége 'your federation', Önök küldöttgyülése 'your general assembly'). This speech also starts with official, detailed address forms, and uses first person plural forms to indicate that the act of greeting is performed on behalf of the international federation.

(10)

Jozef Kliment: Kedves Elnök Úr, kedves vezetőségi tagok, küldöttek és vendégek, kedves barátaim, szeretettel üdvözlünk mindenkit Nyonból, az UEFA központjából [...].

Jozef Kliment: Dear Mr President, dear board members, delegates and guests, dear friends, we are greeting everybody with love from Nyon, the headquarters of UEFA [...].

Most of the subsequent utterances also begin with detailed greeting of the participants, strengthening the formal, official character of the event. Official address forms may also accompany metapragmatic comments on speaker shift.

(11)

Kancz Csaba: Köszönöm szépen a szót, főtitkár úr! Tisztelt elnök úr, alelnök úr, főtitkár úr, tisztelt elnökség, tisztelt küldöttközgyűlés!

Csaba Kancz: Thank you for giving me the word, Mr Secretary General. Dear Mr President, Mr Vice President, dear Mr Secretary General, dear board members, dear delegates! 
The schedule of traditional general assemblies is also followed by the fact that supervisors, attestors of formal order are elected in the online space as well. In compliance with previous practice, the HFF president asks the general secretary to oversee this process.

(12)

[...] Szeretném átadni a szót a főtitkár úrnak, az alapszabályok értelmében erre lehetőség van, az ülés vezetését ő folytatná. Márton, parancsolj!

[...] I would like to give the floor over to Mr General Secretary, according to our bylaws there is an opportunity for this, he is going to chair the assembly from now on. Márton [Martin], please.

It is with the help of such ritual elements that participants of a community define themselves, create and maintain their identities, construe their social relations and regulate the limits of their actions (Andok 2017: 18).

With regard to operations of attitudinal deixis, the official part of the assembly displays the general trend (also attested by the 2019 assembly) that while participants use $T$ forms to address each other, some mentions and address forms are official in nature, and therefore consistently include the address form úr 'sir' along with the name of mentioned participants. This apparently normative practice of the community is exemplified by the fact that although Sándor Csányi uses the given name Márton or even its nickname version Marci to address the secretary general, in his official greeting speech he refers to him in the following way.

(13)

Csányi Sándor: De ennél is még fontosabb, hogy több embert tudtunk a FIFA és az UEFA különböző testületeibe delegálni, így például hogy csak a Vági Márton urat említsem, aki a FIFA egyik legfontosabb bizottságának, ahol én korábban tag voltam, a Pénzügyi Bizottságnak a tagja lett.

Sándor Csányi: But even more importantly, we have been able to delagate a higher number of people to various FIFA and UEFA committees, for example let me only mention Mr Márton Vági, who has become a member of FIFA's Financial Committee, one of the federation's most important committees, where I was also a member before.

In official acts, this way of mentioning persons seems to be a standard, consistently adopted device for creating a formal, official event. It serves to show the community's communicative order, and is efficiently transferred to the online space, as it is wellsuited for the precise identification of the official event's participants. 
(14)

Vági Márton: Sorrendben: Czékmán Lajos úr, Deme Géza úr, egy pillanat türelmet kérek, dr. Olt Mátyás úr, dr. Papp Tibor úr, Jancsurák Zoltán és Varga Balázs urakra lehet szavazni, kérem, tegyétek meg, itt is hosszabbított szavazási időt adunk.

Márton Vági: In order: Mr Lajos Czékmán, Mr Géza Deme, please give me a moment of patience, Dr. Mátyás Olt, Dr. Tibor Papp, Mr Zoltán Jancsurák and Mr Balázs Varga can be voted on, please do vote, here again we'll give you more time for voting.

In the construal of social relations, the practice of employing the address form úr is peculiar because hardly any women participate (or are referred to) in the assembly. The adopted forms give a clear sense of how difficult it is to officially address women in Hungarian (cf. Domonkosi 2019). As a female counterpart of úr 'Mr.', on one occasion hölgy 'lady' is adopted, presumably motivated by analogical pressure because otherwise its use in conjunction with full personal names is far from being common.

(15)

Vági Márton: A javaslatunk szerint az MLSZ küldöttközgyúlés jegyzőkönyvvezetőjének Ács Istvánnét és Sinkáné Johai Mónika hölgyeket választotta meg.

Márton Vági: In line with our recommendation, the HFF general assembly has elected ladies Istvánné Ács and Mónika Sinkáné Johiai as minutes takers.

During one of the votes, which features a female candidate as well, the candidates are introduced collectively by the address form urak'Misters' (15). When the results are presented one by one, each man's name is accompanied by úr 'Mr', whereas the female candidate only appears with her full name at the beginning of the list.

Vági Márton: Elnökségi tagra vonatkozóan nyolc jelöltre, név szerint: Balogh Gabriella, Bánki Erik, Berzi Sándor, Dankó Béla, dr. Anthony Radev, dr. Török Gábor, Garancsi István, és Nyilasi Tibor urakra érkezett megfelelő számú jelölés

Márton Vági: For board membership, eight candidates received a sufficient number of votes, namely Gabriella Balogh and Misters Erik Bánki, Sándor Berzi, Béla Dankó, Dr Anthony Radev, Dr Gábor Török, István Garancsi and Tibor Nyilasi. 
In the Hungarian speech community, officially referring to women in a neutral way is hardly possible due to the lack of a conventional device for this purpose. However, the linguistic phenomena observed at the general assembly under study are probably also motivated by the fact that football and the official roles it is associated with are primarily linked to men.

In the course of official acts, the linguistic construal of relations always reflects the importance of positions/ranks in personal references. Addressing the speech partner by his given name has also been documented, however, typically as a signal that the floor is being given over to this participant (whose official role is also indicated), cf. $(12,17)$.

(17)

Vági Márton: Ezt követően módom van arra, hogy felkérjem Kancz Csaba urat, a mandátumvizsgáló bizottság elnökét. Csaba, átadom a mikrofont.

Márton Vági: After this I have the opportunity to ask Mr Csaba Kancz, chair of the credentials committee. Csaba, the microphone is yours.

In the execution of official acts, it is crucial that they are not simply performed but rather explicitly represented, as if for direct inclusion in the minutes, through the emphatic use of performative verbs. Owing to the prominent role of explicit performatives (cf. Austin 1962: 62-69), a specific kind of meta-narrative is created, which is common in the linguistic practice of official events, forming part of the speech event's conventional manner of instantiation. The communicative style characterized by a heavy use of performative verbs may also result from the fact that acts becoming official through performativity are framed by participants in a way that helps their registration in the minutes. Our data suggest that these features also characterize face-to-face general assemblies, and through the identification of participants and their roles, the accurate registration of events, they make the assembly's ritual well-suited to remain operative in the online space as well. Meta-narrative comments guarantee that an event has indeed officially happened; they make actions symbolic, and they can be interpreted as a linguistic manifestation of rituals. In effect, the chair does not only perform speech acts but also reports them.

(18)

a. Vági Márton: Kérdezem a tisztelt megjelenteket, hogy kíván-e valaki a szavazás előtt hozzászólni.

Márton Vági: I'm asking the dear delegates if anyone would like to make a comment before the vote.

b. Vági Márton: Megállapítom, hogy az eredmény alapján 2\% tartózkodás mellett, 98\%-a a szavazóknak támogatja Kecskés úr újabb 5 
évre való felügyelő bizottsági elnökké való kinevezését, amelyhez az FB elnökének gratulálunk Kecskés úrnak és az ő esetében is kötelességem megköszönni azt a segítő munkát, amit az elmúlt években az MLSZ érdekében kifejtett.

Márton Vági: I establish it that on the basis of the result, with $2 \%$ abstaining, $98 \%$ of voters support the election of Mr Kecskés as president of the supervising committee for an additional 5 years, for which we congratulate the president of the SC Mr Kecskés and also in his case it is my duty to thank him for the supportive work he has carried out in the interest of HFF in recent years.

The explicit and direct representation of official actions and their agents (cf. Hámori 2009) fundamentally contributes to the structure of the official ritual. Along with the official operations of personal reference, this is the linguistic feature that makes it possible for the event to unfold in the online space much as it would as a face-to-face traditional event.

\subsection{The ritual of the online conference}

The organization and agenda of the assembly and the implementation of voting include various elements that result from the computer-mediated and online nature of the event, with official rituals remaining close to those of traditional face-to-face assemblies. These factors shape the technical rituals of the assembly by which shared, regulated action unfold. In the linguistic management of the event, ritualistic operations play a role by the fact that necessary technical actions receive highly detailed, elaborate, specific linguistic reflections. One identifiable person in charge of technical rituals at the event under study is Dr János Tamás Zelei, leader of administrative tasks at HFF.

The preparatory part of the assembly is motivated by the need to set up the technical background and ensure that the participants are identified; on top of these functions, it also makes personal conversations possible. As a function of his role, Dr János Tamás Zelei's linguistic behaviour is strictly formal, reinforcing official protocol. When the president joins the meeting, he is greeting him with an official vocative phrase, which is also repeated in his second utterance addressed to him.

(19)

Dr. Zelei János Tamás: Jó napot kívánok, elnök úr, épp most ellenőrizzük a jelenlévők létszámát, mihelyst megvan, ezt jelezzük Önnek, és kezdhetjük is a küldöttközgyűlést.

Dr János Tamás Zelei: Good afternoon, Mr President, we have just checked the number of participants present, as soon as we have done this, we'll let you know and we can start the assembly. 
Despite the official nature of the event, participants generally use T forms as they knew each other well. Meanwhile, Dr János Tamás Zelei's role as an organizer is linguistically made prominent by the fact that he remains on mutual $\mathrm{V}$ terms with the president throughout the meeting. In the opening part of the recording, at Sándor Csányi's request, he gives an elaborate discussion of how the official procedure of joining the assembly has been technically implemented.

Such linguistic reflection on technical aspects of the assembly supplements the operations mentioned in Section 4.3 with which official acts are performed. In terms of linguistic structure, these operations contribute to the adjustment of the general assembly's protocol to the online space by involving concrete, straightforward instructions, directive speech acts directed at participants. The linguistic operations for establishing rules and protocol, as indeed the entire official procedure, are primarily performed by the chair Márton Vági.

(20)

Vági Márton: Fogom kérni akkor a programnak a hostját, hogy indítson el egy szavazást. És kérem, hogy mindenki válasszon egy igen, vagy nem, egy tartózkodom gombot, majd azt követően, ha megnyomja a szavazásnak a submit feliratát a szavazólap alján, azzal el is küldi a szavazatát. Kérem, hogy ezt tegyétek meg akkor, legyetek szívesek.

(.)

Jó, köszönöm, láthatóan akkor a közgyúlés elfogadta a levezető elnök személyére tett javaslatot, akkor a továbbiakban vezetném a közgyülést.

Márton Vági: I'd like to ask the host of the programme to launch a vote. And I'm asking everyone to choose one of the buttons yes, no, or abstain, and then when you press the submit button at the bottom of the voting sheet, your vote will be submitted. Please do this then.

(.)

OK, thank you, it can be seen that the general assembly has accepted the suggestion about the chair's person, so from now on I'm going to chair the assembly.

Some instructions related to the technical background are formulated directly, with second person T forms. Besides these, first person plural forms are also common, and help shape shared norms, shared practices through the joint actions they designate.

(21)

A sok lehetőséget, amit nyújt ez az informatikai háttér, azt most ne próbálgassuk, és ne használjuk túlzott mértékben. Tehát amit hasz- 
náljunk, az alapvetően két gomb legyen: az egyik a mikrofon be- és kikapcsolása, ami a képernyő alján, a legtöbbünknek a képernyő alján egy ikonsorozatnak bal szélén szerepel, ami ha rákattintotok, akkor vagy bekapcsolja a mikrofonotokat, vagy kikapcsolja értelemszerúen. Az a kérésünk, hogy az összes résztvevő tekintetében végig legyen kikapcsolt állapotban ez a mikrofon, kivéve azt, amikor azt illető szólni kíván, és én erre én megadom a szót.

The many opportunities that this IT infrastructure offers, let's not try all of them and let's not use them beyond necessity. So what we use should be basically two buttons, one is the for switching the microphone on and off, and it is at the bottom of the screen, for most of us on the left edge of a series of icons, and then when you press it, it either turns your microphone on or it turns it off obviously. Our request is that all participants keep their microphones switched off throughout the meeting, except when somebody wants to talk and I give him the floor.

The identity of those providing technical assistance to the chair remains in the background, or it is construed in third person, with a neutral vantage point (20), or else a first person plural form used, as a way of avoiding direct reference or addressing of the person who is actually performing the action.

(22)

Vági Márton: Kérem, hogy indítsuk el a szavazást 20 másodpercig.

Márton Vági: I'm asking that we launch a vote for 20 seconds.

\subsection{References to the epidemic situation in the rituals of greetings and good wishes}

Throughout the video conference, the epidemic situation is naturally often raised as a topic, and the communicative situation triggered by the problem receives elaborate comments. However, for a study of how social relations are construed, it is not the thematization of the epidemic that has relevance but rather ritual elements that find their way into greetings and good wishes (cf. DomonkosiLudányi 2020). In the closing part of his annual report, president Sándor Csányi expresses good wishes in the following slogan-like fashion.

(23)

Csányi Sándor: Mindenkinek jó egészséget kívánok, mindenki vigyázzon magára, játékosaira, csapatokra és hát bízom benne, hogy ez csak egy, ha nem is rövid, de nem túl hosszú epizód a magyar labdarúgás történetében, ami most történik. 
Sándor Csányi: I wish everyone good health, everybody please look after yourselves, your players, the teams and well I hope that even if this is not a short episode, it is also not going to be a long one in the history of Hungarian football, what is happening now.

A good wish about health also appears in the opening of the following utterance by Tamás Lelkes, the auditor of HFF.

Vági Márton: Lelkes úrnak adnám meg a szót.

Lelkes Tamás: Köszönöm szépen! Én is üdvözlök mindenkit, és jó egészséget kívánok! [...]

Márton Vági: I'd like to give the floor to Mr Lelkes.

Tamás Lelkes: Thank you very much. I am also greeting everyone and I wish you good health.

[...]

At the beginning of his speech, UEFA delegate Jozef Kliment reflects on the ongoing situation. The speech concludes with good wishes.

(25)

a. Jozef Kliment: Szeretettel üdvözlünk mindenkit Nyonból, az UEFA központjából ezen a szokatlan módon. Rendkívüli időket élünk a koronavírus okán, és ez a helyzet rákényszerít minket a rendkívüli megoldásokra.

b. Jozef Kliment: Kívánok Önöknek nagyon hatékony közgyúlést, és mindannyiuk számára jó egészséget, lelkesedést és pozitív energiát a magyar futball érdekében végzett munkájukhoz!

a. Jozef Kliment: I am happy to greet everyone from Nyon, from the UEFA headquarters, in this unusual way. We are witnessing extraordinary times because of the coronavirus, and this situation forces us to adopt extraordinary measures.

b. Jozef Kliment: I wish you a very fruitful general assembly and also good health, enthusiasm and positive energy in your work for Hungarian football.

In his speech that closes the entire general assembly, the federation's president also adopts a health-related formula in the act of farewell, supplemented by references to the ongoing situation and to the possibility of organizing football matches again. 
(26)

Csányi Sándor: Bízom benne, hogy úgy alakul, hogy tudunk úgy dönteni, hogy újra a pályán találkozzunk és nem a képernyők előtt. Köszönöm szépen a bizalmat még egyszer, és hát jó munkát, jó egészséget kívánok mindenkinek!

Sándor Csányi: I hope it's going to be possible for us to decide that we meet in the stadiums again and not in front of computer screens. Thank you for your trust once again, and well, I wish you all good work and good health.

Good wishes linked to shared experiences of the epidemic and health-related references demonstrate the flexibility with which the rituals of greeting are adapted to aspects of particular social situations.

\section{Summary}

In the new communication protocol that emerged during the lockdown period, multi-participant video calls attained special significance, as these were meant to compensate for the loss of face-to-face encounters from friends' meetings, family parties through lessons to scientific conferences and business negotiations. At the event analysed in this paper, previously separate features characterizing different communicative situations, forms and roles become blurren in the wake of changes in the spatial and temporal conditions defining particular communicative situations.

The strictly formal, protocol-based overall framework of general assemblies is cross-cut by informal behavioural practices among participants knowing each other to varying degrees. The novel communicative situation also requires new kinds of skills, especially in the areas of digital communication and its technical infastructure. At the same time, the linguistic organization of the assembly's ritual, notably explicit speech acts and official person-marking devices allow the social event to be implemented in the online space similarly to how it traditionally would.

The analysis suggests that a study of variants of attitudinal deixis is wellsuited for modelling the dynamics of different communicative situations. In the community of participants at the event under study, the general and mutual, solidarity-based use of $T$ is typical, with $V$ forms only marking situations which are particularly official. In addition, the formal, protocollary nature of the event is indicated by nominal forms referring to positions and widespread use of the úr 'Mister' form, supplementing family names. The appearance of more confidential forms, i.e. given names and nicknames, can be motivated by the fact that personal relations are brought on stage, and by the increased attention 
that is devoted to online conversation management (e.g. the operation of giving over the floor to the next speaker).

The study of online events during the lockdown period can also inform the understanding of which aspects of novel practices can be preserved even after the epidemic. In this regard, the results of our study suggest that in the area of phatic, personal, relationship-building communication, the online space is substantially different from what traditional opportunities afford. At the same time, partly because of the formalized nature of language activity, official, ceremonial acts such as voting by a high number of delegates can also be successfully performed via online communication.

\section{WEB SOURCES}

W1 = https://szovetseg.mlsz.hu/hir/tajekoztato-a-kuldottkozgyulesrol (2020. 06. 10.)

W2 = https://haon.hu/sport/helyi-sport/foprobaval-keszultek-az-mlsz-onlinekozgyulesere-3985170/ (2020. 06. 10.)

W3 = https://szovetseg.mlsz.hu/hir/kozgyulesre-keszul-az-mlsz (2020. 06. 10.)

W4 = https://szovetseg.mlsz.hu/hir/kituzte-a-jovo-evi-kozgyules-idopontjat-az-

elnokseg (2020. 06. 10.)

W5 = https://www.youtube.com/watch?v=9ddAsYYiHuU (2020. 06. 10.)

W6 = http://index.indavideo.hu/video/Az_MLSZ_2020_evi_rendes_kuldott kozgyulese (2020. 06. 10.)

W7 = https://szovetseg.mlsz.hu/hir/eloben-az-mlsz-eves-kozgyulese (2020. 12. 10.)

\section{BIBLIOGRAPHY}

Alexander, John C. 2004. Cultural Pragmatics: Social Performance between Ritual and Strategy. Sociological Theory 22/4: 527-573.

https://doi.org/10.1111/j.0735-2751.2004.00233.x

Andok, Mónika 2016. Digitális média és mindennapi élet. [Digital media and everyday life.] Budapest: L'Harmattan Kiadó.

Andok, Mónika 2017. A kommunikáció rituális elmélete. [The ritual theory of communication.] Budapest: Gondolat Kiadó.

Austin, John L. 1962. How to do things with words. Oxford: The Clarendon Press. Balázs, László 2010. A szerepviselkedés szociálpszichológiai háttere. [The social psychological background of role behaviour.] In: H. Varga Gyula (ed.): A kommunikációoktatás kontextusai. Budapest: Hungarovox Kiadó. 44-54.

Borgulya, Ágnes 2007. Üzleti kommunikáció élőszóban. [Business communication in spoken discourse.] In: Borgulya Ágnes - Somogyvári Márta: Kommunikáció az üzleti világban. Budapest: Akadémiai Kiadó. 168-193. 
Boronkai, Dóra 2009. Bevezetés a társalgáselemzésbe. [Introduction to conversation analysis.] Budapest: Ad Librum.

Bös, Birte - Kleinke, Sonja 2017. Publicness and privateness. In: Bublitz, Wolfram Hoffman, Christian (eds.): Pragmatics of Social Media. Handbooks of Pragmatics 11. Berlin, Boston: Gruyter Mouton. 83-121. https://doi.org/10.1515/9783110431070-004

Buda, Béla 1994. A közvetlen emberi kommunikáció szabályszerüségei. [Regularities of direct human communication.] Budapest: Animula Kiadó.

Dessewffy, Tibor - Láng, László 2015. Big Data és a társadalomtudományok véletlen találkozása a mútőasztalon. [The accidental meeting of Big Data and social sciences on the operating table.] Replika 92-93: 157-170.

Domonkosi, Ágnes 2018a. Nyilvánosság és attitűddeixis a közösségi oldalak diskurzusaiban. [Publicity and attitudinal deixis in discourses on social media.] Alkalmazott Nyelvészeti Közlemények 13/2: 63-75.

Domonkosi, Ágnes 2019. The role of gender in the use of Hungarian address forms. Język. Komunikacja. Informacja 13: 175-187.

Domonkosi, Ágnes - H. Tomesz, Tímea 2020a. Protokoll vs. személyes jelenlét, ünnepélyesség vs. bizalmasság. A társas deixis műveletei egy sportolói díjátadó ünnepségen. [Protocol vs. personal presence, solemnity vs. intimacy. Operations of social deixis at a sports award ceremony.] In: H. Varga Gyula (ed.): Személyközi és médiakommunikációs tudatosság az iskolában. Budapest: Hungarovox Kiadó. 181-194.

Domonkosi, Ágnes - H. Tomesz, Tímea 2020b. Az attitűddeixis műveletei közvetített médiaesemények társas viszonyainak alakításában. [Operations of attitudinal deixis in the construal of social relations at broadcast media events.] Hungarológiai Közlemények 21/3: 31-47.

https://doi.org/10.19090/hk.2020.3.31-47

Domonkosi, Ágnes - Ludányi, Zsófia 2020. Társas távolságtartás és nyelvi közeledés. E-mailezési gyakorlatok a koronavírus idején. [Social distancing and linguistic proximity. Emailing practices at the time of the coronavirus] In: Kovács László (ed.): Globális kihívás - lokális válaszok: A koronavírus (Covid19) gazdasági és társadalmi összefüggései és hatásai. Szombathely: Savaria University Press. 241-260.

Goffmann, Erving 1956. The presentation of self in everyday life. New York: Anchor. Hámori, Ágnes 2009. A figyelem és a beszédaktusok összefüggései a társalgásban. [Relations between attention and speech acts in conversation.] Ph.D. thesis. Budapest: ELTE Faculty of Humanities.

Hymes, Dell 1974. Foundations of Sociolinguistics: An Ethnographic Approach. Philadelphia: University Press.

Leech, Geoffrey N. 1983. Principles of Pragmatics. London: Longman.

Kádár, Zoltán Dániel 2013. Relational Rituals and Communication. Basingstoke:

Palgrave Macmillan. https://doi.org/10.1057/9780230393059 
Kádár, Zoltán Dániel - Petykó, Márton 2016. A bekiabálás vizsgálata mimetikus és személyközi nézőpontból. [Exploring heckling from a mimetic point of view.] Argumentum 12: 1-31.

Sebestyén, Eszter - Gayer, Zoltán 2016. Az ó- és új nyilvánosság, mint önmagába térő ösvény. [Old and new media as a path leading back to itself.] Médiakutató 17/3-4: 139-153.

Pólya, Tamás 2011. A számítógépes kommunikáció mediális sajátosságairól. Hoznak-e újat a (digitális) új médiumok a személyközi kommunikációban? [On the medial features of computer-mediated communication. Do (digital) new media bring something new in interpersonal communication?] In: Martin József - Széchenyi Ágnes (szerk.): Klió és a médiagalaxis. Tanulmányok a 70 éves Buzinkay Géza tiszteletére. Budapest: Corvina Kiadó. 247-271.

Szűts, Zoltán 2018. Online. Az internetes kommunikáció és média története, elmélete és jelenségei. [Online. The history, theory and phenomena of internet communication and media.] Budapest: Wolters Kluwer Kiadó.

Tátrai, Szilárd 2011. Bevezetés a pragmatikába. Funkcionális kognitív megközelítés. [Introduction to pragmatics. A functional cognitive approach.] Budapest: Tinta Könyvkiadó.

Tátrai, Szilárd - Ballagó, Júlia 2020. A stílustulajdonítás szociokulturális szituáltsága. Funkcionális kognitív pragmatikai megközelítés. [The sociocultural situatedness of style attribution. A functional cognitive pragmatic approach.] Magyar Nyelvőr 144/1: 1-43. https://doi.org/10.38143/Nyr.2020.1.1 Verschueren, Jef 1999. Understanding pragmatics. London: Edward Arnold, New York, Sydney: Oxford University Press.

\section{A társas viszonyok nyelvi alakítása az MLSZ online közgyủlésén}

A koronavírus-járvány miatt bevezetett intézkedések következtében a közösségi tevékenységek nagy része az online térbe került át, ennek következtében pedig egyes kommunikációs gyakorlatok, rítusok is átértékelődtek. A tanulmány célja annak elemzése, hogy az MLSZ online küldöttgyűlésén hogyan valósul meg a társas viszonyok nyelvi alakítása. Az elemzés a teljes rögzített anyagot feldolgozva esettanulmányként mutatja be, hogy milyen sajátosságok jellemzőek az online videókonferencia keretében megtartott formális és nyilvános esemény nyelvi szerveződésére, illetve hogy az újszerü kommunikációs helyzet hogyan járul hozzá a nyelvi és nem nyelvi rítusok működéséhez. Az értelmezés a kommunikáció rituális felfogására épül, az elemzés a társas viszonyok szerveződését az attitűddeixis legfőbb műveleteinek, azaz a megszólításoknak, üdvözléseknek, személyemlítéseknek az elemzése révén tárja fel. 